\title{
GERMAN DEMOCRATIC REPUBLIC
}

As the International Review announced in May 1975, the Florence Nightingale Medal was awarded, in the twenty-fifth award of this honour, to Sister Ilse Giese, an auxiliary nurse and voluntary aid. The medal and the diploma accompanying it were presented at a ceremony marking the anniversary of the German Red Cross in the German Democratic Republic. ${ }^{1}$

In a message to the ICRC, the National Society has informed us both of the joy of the recipient and the pride felt by the members of the Red Cross. The message reports that wide publicity was given to the event, which was announced and commented upon by both newspapers and television in the German Democratic Republic.

\section{JAPAN}

As we have previously reported, Mrs. Sachiko Hashimoto, former director of the Japanese Junior Red Cross became the moving spirit of the Henry Dunant Study Center in that country. Founded at Tokyo on 8 May 1974, the Center developed a series of projects, not only to familiarize people with the personality and achievements of Henry Dunant but also to provide for diffusion throughout Japan of Red Cross principles and the Geneva Conventions.

\footnotetext{
1 Plate.
} 